\title{
Pemberdayaan Masyarakat melalui Pelatihan Komunikasi Efektif bagi Kader Posyandu
}

\author{
Ngatoiatu Rohmani ${ }^{1}$, Dewi Utari ${ }^{2}$ \\ 1,2 Universitas Jenderal Achmad Yani Yogyakarta, Indonesia
}

\begin{abstract}
A B S T R A C T
COMMUNITY EMPOWERMENT TROUGH EFFECTIVE COMMUNICATION TRAINING FOR COMMUNITY HEALTH VOLUNTEER (CADRE) OF POSYANDU. Community participation for creating Indonesia's health development is necessary. One of manifestation of community empowerment is through Posyandu activities that are managed by community health volunteers (cadre) with the aim of providing facilities to the public in obtaining basic health services as a promotive and preventive health strategy in community. Cadres as the driving agent need to be equipped with health promotion skills as an attempt to create national health development optimally. The purpose of this community service is to provide knowledge of effective communication, and to introduce of communication media for promoting of health information. The methods of conducting communication training include: survey activities, communication training, preparing health promotion media and evaluation. The results of the training showed that participants had good communication skills, participants were able to practice effective communication techniques and realized the importance of the media to promote Posyandu activities.
\end{abstract}

Keywords: Cadre, Community empowerment, Effective communication, Posyandu.

\begin{tabular}{llll}
\hline Received: & Revised: & Accepted: & Available online: \\
10.10 .2019 & 11.01 .2020 & 29.01 .2020 & 14.02 .2020 \\
\hline
\end{tabular}

\section{Suggested citation:}

Rohmani, N., \& Utari, D. (2020). Pemberdayaan masyarakat melalui pelatihan komunikasi efektif bagi kader Posyandu. Jurnal Pengabdian Pada Masyarakat, 5(1), 167-174. https://doi.org/10.30653/002.202051.271

Open Access I URL: http://ppm.ejournal.id/index.php/pengabdian/article/view/271

\footnotetext{
1 Corresponding Author: Ngatoiatu Rohmani: Program Studi Pendidikan Profesi Ners, FKes Universitas Jenderal Achmad Yani Yogyakarta. Jl. Brawijaya, Ambarketawang, Gamping, Sleman, Yogyakarta. Email: rahmanigp@gmail.com
} 


\section{PENDAHULUAN}

Program Indonesia Sehat merupakan wujud dari pembangunan kesehatan nasional yang didalamnya menekankan pada peningkatan derajat kesehatan dan status gizi masyarakat melalui upaya kesehatan dengan penguatan upaya preventif, promotif dan pemberdayaan masyarakat (Kementerian Kesehatan RI, 2016). Guna menunjang program tersebut, tentunya Pemerintah memerlukan dukungan dan partisipasi dari para pemangku dan petugas pelayanan kesehatan di tingkat pertama agar program dapat berjalan optimal.

Permasalahan kesehatan balita menjadi salah satu fokus kesehatan yang selalu mendapatkan perhatian dari pemerintah. Upaya pemerintah untuk menangani permasalahan tersebut diwujudkan dalam kegiatan Posyandu. Penyelenggaraan dan pengelolaan posyandu dilakukan oleh kader bekerjasama dengan pihak Puskesmas setempat. Kegiatan posyandu dilakukan setiap satu bulan sekali sebagai upaya promotif dan preventif di masyarakat. Jumlah Posyandu di Indonesia pada tahun 2018 tercatat sebanyak 291.447 yang tersebar di seluruh wilayah, akan tetapi jumlah Posyandu aktif hanya 56.5\% dari total Posyandu yang ada (Kementerian Kesehatan RI, 2018). Selain itu, berdasarkan profil kesehatan RI (2018) menunjukkan bahwa cakupan penimbangan berat badan $\geq 4$ kali pada balita 6 - 59 bulan di Indonesia masih dibawah angka $80 \%$.

Kabupaten Bantul merupakan salah satu wilayah di Yogyakarta yang memiliki permasalahan kesehatan balita cukup tinggi khususnya masalah gizi buruk dan kurang. Kabupaten ini memiliki prevalensi KEP (Kurang Energi Protein) sebesar 8.04 yang menempati urutan ke 3 setelah kabupaten Yogyakarta (Dinas Kesehatan Provinsi DIY, 2018). Selain itu, AKB (Angka Kematian Bayi) di wilayah kabupaten Bantul pada Tahun 2017 tercatat melebihi rata-rata AKB DIY yakni sebesar 8.74. Salah satu wilayah kabupaten Bantul yang memiliki AKB lebih 5 - 7 bayi di Tahun 2017 adalah kecamatan Pajangan, Bantul. Serupa dengan itu, angka kematian balita di kecamatan tersebut juga cukup tinggi yakni > 7 balita di Tahun 2017 (Dinas Kabupaten Bantul, 2018). Hal tersebut tentunya perlu menjadi perhatian lebih bagi Puskesmas dan masyarakat agar dapat meningkatkan derajat kesehatan masyarakat.

Tingginya angka kematian bayi dan balita yang disebabkan oleh penyakit seperti diare di wilayah Puskesmas Pajangan tentunya dapat diminimalisir melalui pemeriksaan kesehatan berkala di Posyandu. Untuk itu, kader sebagai tokoh kesehatan masyarakat memiliki peran dan tugas penting dalam menumbuhkan dan meningkatkan kesadaran masyarakat untuk hidup sehat. Sehingga, kader perlu dibekali ketrampilan khusus agar dapat menjalankan perannya sebagai penggerak masyarakat karena kader adalah sumber daya manusia yang merupakan modal utama dalam pembangunan nasional. Untuk menunjang tugasnya, kader perlu memahami bagaimana melakukan komunikasi secara efektif kepada masyarakat agar mereka termotivasi menggunakan fasilitas kesehatan di lingkungannya sebagai upaya pencegahan terhadap permasalahan kesehatan.

Kemampuan komunikasi seseorang dapat berpengaruh pada respon penerimaan pada sasaran komunikasi. Penelitian Arianto (2015) menunjukkan bahwa komunikasi dalam suatu organisasi dapat memengaruhi semangat kerja karyawan dalam organisasi tersebut. Semakin intens komunikasi dilakukan baik dari atasan ke bawahan ataupun 
sebaliknya, maka semangat kerja juga semakin meningkat. Komunikasi dapat diartikan sebagai pertukaran pikiran, pesan, atau informasi melalui perkataan, sinyal, tulisan atau perilaku (Marquis \& Huston, 2017). Komunikasi dapat berupa komunikasi verbal dan non verbal seperti cara berpakaian dan gestur tubuh. Komunikasi yang efektif dapat dilakukan apabila seseorang yang berkomunikasi memahami tentang pengertian dari komunikasi efektif, proses komunikasi efektif dan unsur-unsur komunikasi efektif (Suprapto, 2017).

Berdasarkan situasi di atas, dipandang perlu untuk memberikan pelatihan ketrampilan komunikasi bagi kader Posyandu yang bertujuan untuk memberikan pengetahuan kepada kader posyandu wilayah Pajangan mengenai komunikasi efektif, mengajarkan teknik berkomunikasi secara efektif pada anggota masyarakat dan bagaimana memanfaatkan media komunikasi dalam penyebaran informasi kesehatan.

\section{METODE}

Kegiatan pelatihan komunikasi efektif bagi kader Posyandu di Desa Triwidadi, Pajangan, Bantul dilaksanakan dengan metode sebagai berikut:

\section{Tahap Survei ketrampilan komunikasi}

Survei dilakukan menggunakan kuesioner kemampuan komunikasi efektif yang terdiri dari 6 pertanyaan berdasarkan rating scale untuk menilai kemampuan kader dalam berkomunikasi secara efektif di masyarakat.

\section{Tahap Ceramah}

Ceramah dilakukan untuk memberikan pengetahuan tentang dasar komunikasi efektif meliputi pengertian, unsur dan proses komunikasi. Dalam tahap ini juga diberikan video simulasi komunikasi efektif untuk memberikan pemahaman lebih teknik berkomunikasi secara efektif.

\section{Tahap Interaktif dan praktik}

Tahap ini memberikan kesempatan pada peserta untuk bertanya terkait materi dan sharing pengalaman dalam penyelenggaraan posyandu di wilayahnya. Pertanyaan peserta tidak terbatas pada materi yang diberikan, peserta dapat bertanya diluar materi tapi masih relevan dengan topik. Selain itu, pada tahap ini peserta diminta untuk melakukan simulasi komunikasi efektif sebagai penyuluh dan peserta penyuluhan.

\section{Tahap Pengenalan media}

Kegiatan ini memberikan contoh media komunikasi berupa poster yang dapat digunakan sebagai sarana promosi kegiatan posyandu di masyarakat. Peserta juga diberikan teknik dan tips membuat media promosi yang sesuai dengan sasaran kegiatan kesehatan.

\section{Tahap Evaluasi}

Tahap ini dimaksudkan untuk mengukur ketercapaian program dengan memberikan 5 pertanyaan kepada peserta untuk dijawab untuk menilai peningkatan pengetahuan dan pemahaman peserta mengenai materi yang diberikan. 


\section{HASIL DAN PEMBAHASAN}

Pelaksanaan kegiatan pelatihan komunikasi efektif telah dilaksanakan pada bulan Agustus 2019 di rumah dukuh Jogonandan. Peserta kegiatan adalah kader desa Triwidadi, Pajangan, Bantul yang berjumlah 30 orang dengan karakteristik sebagai berikut:

Tabel 1. Peserta kegiatan pengabdian kepada masyarakat

\begin{tabular}{llcc}
\hline Karakteristik & \multicolumn{1}{c}{ Keterangan } & Frekuensi & Persentase \\
\hline Jenis kelamin & Perempuan & 29 & 96.7 \\
& Laki-laki & 1 & 3.3 \\
Tingkat & SD & 2 & 6.7 \\
pendidikan & SMP & 13 & 43.3 \\
& SMA & 15 & 50.0 \\
Pekerjaan & Tidak bekerja/ IRT & 22 & 73.3 \\
& Petani/ Buruh & 4 & 13.3 \\
& Wiraswasta & 3 & 10.0 \\
\multirow{5}{*}{ Pengalaman } & PNS/ Swasta & 1 & 3.3 \\
& $\leq 5$ tahun & 4 & 13.3 \\
& 6- 10 Tahun & 10 & 33.3 \\
& P10 tahun & 16 & 53.3 \\
& Tidak & 7 & 23.3 \\
& Ya & 23 & 76.7 \\
\hline
\end{tabular}

Peserta pelatihan komunikasi efektif didominasi oleh perempuan (97.3\%) dengan $50 \%$ berpendidikan SMA/ sederajat. Mayoritas kader adalah ibu rumah tangga dengan pengalaman $>10$ tahun menjadi kader. Jika dilihat dari tingkat pendidikan kader, dapat disimpulkan bahwa kader desa Triwidadi telah memenuhi syarat minimal sebagai kader yakni mampu membaca dan menulis (Kementerian Kesehatan RI, 2012). Selain itu, pekerjaan kader yang sebagian besar adalah ibu rumah tangga, menjadi poin penting karena kader diharapkan memiliki waktu yang fleksibel dan leluasa untuk dapat menjalankan program posyandu di masyarakat (Ismawati, Pebriyanti dan Proverawati, 2010). Sebanyak $76.7 \%$ kader telah mendapatkan pelatihan berupa penimbangan berat badan, pengisian KMS, pengukuran gizi balita dan administrasi Posyandu. Belum ada kader yang pernah mendapatkan pelatihan terkait kepemimpinan dan komunikasi efektif.

Sebelum pemberian materi komunikasi efektif, kader diminta untuk mengisi kuesioner untuk menilai kemampuan kader dalam berkomunikasi efektif dengan menggunakan skala rating 1-3. Pada umumnya kader desa Triwidadi telah mampu melakukan komunikasi efektif secara baik dengan nilai mean $\bar{x}$ 2.5. Dari ke enam item kemampuan komunikasi, item no 5 memiliki poin terendah dibandingkan dengan item lainnya ( $\bar{x} 2.2$ ), yang berarti kader merasa belum mampu menyusun kata-kata dengan baik saat berbicara dengan orang lain. Selain itu, kader juga merasa belum mampu untuk berbicara langsung pada intinya sehingga cenderung bertele-tele. Sedangkan berdasarkan jumlah prosentase pada tiap-tiap poin dalam pertanyaan, dapat diketahui bahwa masih ada kader yang merasa bahwa perkataannya belum ditanggapi dengan 
baik oleh lawan bicara dan tidak mampu berbicara langsung ke inti (3.3\%). Sebagian besar responden merasa bahwa pengucapan kata-kata saat berkomuniskasi sudah jelas (76.7\%).

Tabel 2. Hasil Kuesioner Komunikasi Efektif Kader

\begin{tabular}{lllll} 
Pernyataan & 1 & 2 & 3 & Mean \\
\hline
\end{tabular}

\begin{tabular}{|c|c|c|c|c|c|}
\hline 1) & $\begin{array}{l}\text { Saat berkomunikasi, orang yang saya ajak } \\
\text { berbicara mengerti apa yang saya } \\
\text { sampaikan }\end{array}$ & $0 \%$ & $16.7 \%$ & $83.3 \%$ & 2.8 \\
\hline 2) & $\begin{array}{l}\text { Lawan bicara saya menaggapi } \\
\text { pembicaraan sesuai dengan harapan saya }\end{array}$ & $3.3 \%$ & $53.3 \%$ & $43.4 \%$ & 2.4 \\
\hline 3) & Ucapan saya jelas saat berkomunikasi & $0 \%$ & $23.3 \%$ & $76.7 \%$ & 2.8 \\
\hline 4) & $\begin{array}{l}\text { Saya dapat menangkap semua yang } \\
\text { dikatakan oleh lawan bicara }\end{array}$ & $0 \%$ & $36.7 \%$ & $63.3 \%$ & 2.6 \\
\hline 5) & $\begin{array}{l}\text { Saya dapat menyusun kata-kata dengan } \\
\text { baik ketika saya berbicara }\end{array}$ & $0 \%$ & $76.7 \%$ & $23.3 \%$ & 2.2 \\
\hline 6) & $\begin{array}{l}\text { Saya mampu berbicara langsung pada inti } \\
\text { pembicaraan }\end{array}$ & $3.3 \%$ & $63.3 \%$ & $33.4 \%$ & 2.3 \\
\hline & Nilai mean total item & & & & 2.5 \\
\hline
\end{tabular}

Ket: 1 Tidak pernah; 2 Kadang-kadang; 3 Sering

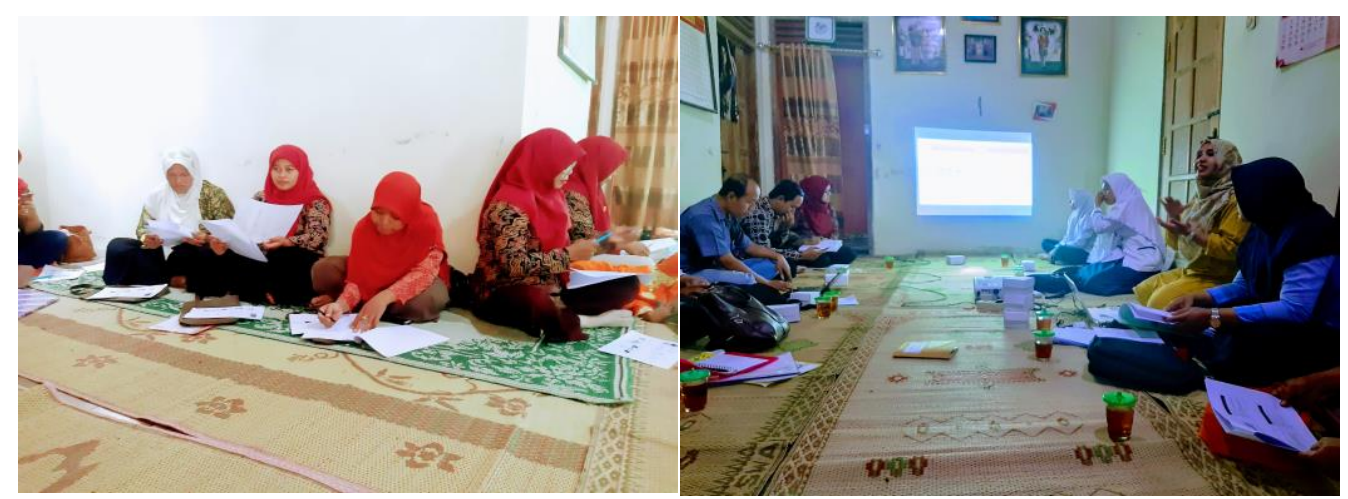

Gambar 1. Kegiatan pengisian kuesioner dan ceramah materi dasar komunikasi

Pada akhir sesi materi, kader diberikan video role play teknik berkomunikasi secara efektif dalam kehidupan sehari-hari serta dilakukan diskusi terkait komunikasi dan pengalaman kader dalam penyelenggaraan posyandu di wilayahnya. Salah satu kader juga berhasil melakukan simulasi komunikasi efektif pada saat kegiatan penyuluhan di posyandu. Kegiatan kemudian dilanjutkan dengan pengenalan media promosi kesehatan yang dapat digunakan dalam penyebaran informasi kegiatan Posyandu di masyarakat. Media promosi yang dipilih berupa poster yang memuat gambar yang mengandung pesan agar masyarakat mau memanfaatkan Posyandu sebagai fasilitas kesehatan bagi ibu dan anak di masyarakat. 


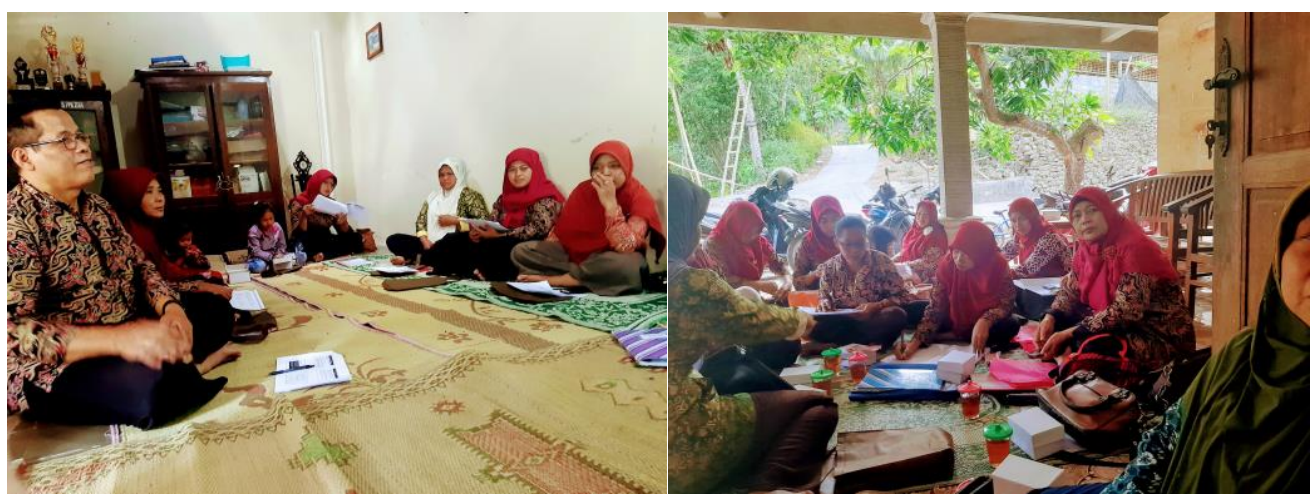

Gambar 2. Sesi interaktif dan simulasi penyuluhan

Di era teknologi yang berkembang pesat ini, peran media informasi menjadi sangat penting. Masyarakat cenderung sangat mudah mendapatkan informasi kesehatan melalui media massa, sosial ataupun elektronik. Media promosi kesehatan yang tepat dapat menjadi alat bantu yang berfungsi untuk memperlancar komunikasi, menyiarkan dan menyebarluaskan informasi kesehatan. Media terbukti membantu kader dalam melaksanakan tugas-tugas Posyandu (Wardani, Martanti, \& Wahyudi, 2019). Media promosi sebaiknya mudah dimengerti oleh masyarakat, menarik pusat perhatian dan dapat memberikan motivasi bagi yang melihatnya (Andayani et al., 2019). Kader tentunya perlu dibekali dengan ketrampilan pembuatan media promosi kesehatan guna menunjang kegiatan promosi kesehatan yang ada di masyarakat.

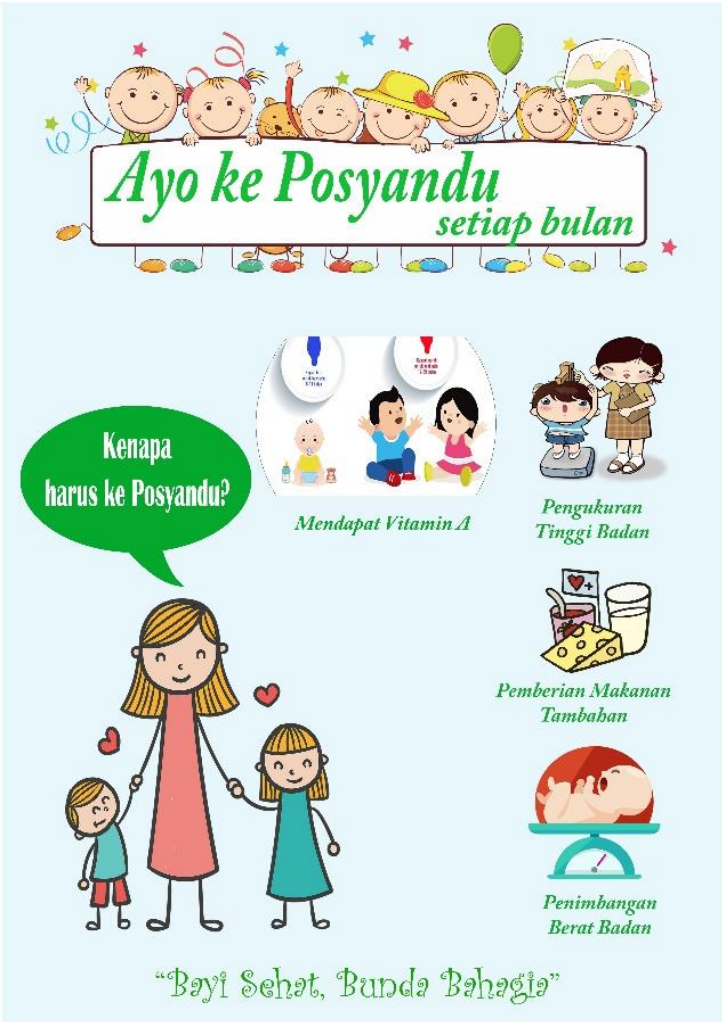

Gambar 3. Poster promosi kegiatan posyandu 
Komunikasi interpersonal yang efektif merupakan modal dasar bagi kader dalam melaksanakan promosi kesehatan dan menjalankan peran serta tugas sebagai penggerak masyarakat. Berdasarkan diskusi saat sesi interaktif, dapat disimpulkan bahwa sebagian besar kader wilayah Puskesmas Pajangan mampu bekerjasama dengan masyarakat dalam meyebarkan informasi kegiatan posyandu dan memiliki hubungan yang baik dengan sesama kader. Hanya saja masih ada kader yang terkadang belum menginformasikan jadwal kegiatan posyandu selanjutnya kepada peserta posyandu. Sebagian kader juga merasa belum mampu untuk memberikan solusi dan nasihat pada peserta posyandu terkait permasalahan kesehatan yang dihadapi mereka.

Kegiatan penyuluhan merupakan bagian dari kegiatan posyandu yang bisa diselenggarakan secara perorangan, atau kelompok. Untuk itu kader perlu menguasi beberapa ketrampilan dan pengetahuan seperti komunikasi efektif, penimbangan balita, pencatatan dan pelaporan serta pengetahuan kesehatan dasar dan gizi agar pelayanan kesehatan lebih optimal.

\section{SIMPULAN}

Kegiatan pelatihan komunikasi efektif bagi kader Posyandu di wilayah kerja Puskesmas Pajangan telah berlangsung dengan lancar. Sejumlah 30 kader mampu mengikuti kegiatan pelatihan dengan baik. Berdasarkan survey, kader desa Triwidadi telah mampu melakukan komunikasi efektif dengan cukup baik. Selain itu, sebagian besar kader telah mampu bekerjasama dengan masyarakat dalam meyebarkan informasi kegiatan posyandu dan memiliki hubungan yang baik dengan sesama kader. Dengan pengetahuan ini diharapkan para kader mau menerapkan teknik komunikasi yang efektif saat kegiatan Posyandu berlangsung.

Pemanfaatan teknologi sebagai media informasi kesehatan dalam kegiatan posyandu masih perlu ditingkatkan. Kader perlu diberikan ketrampilan dalam penggunaan teknologi seperti media sosial sebagai alat dalam penyebaran informasi kegiatan Posyandu di masyarakat. Selanjutnya, kegiatan pelatihan komunikasi bagi kader Posyandu diharapkan rutin dilaksanakan dengan menambahkan waktu role play dan menjangkau lebih banyak kader-kader di daerah-daerah lain.

\section{REFERENSI}

Andayani, S. A., Khotimah, H., Desy, S., Trilianto, A. E., \& Razaq, H. (2019). Efektivitas promosi kesehatan menggunakan media audiovisual terhadap keaktifan lansia ke Posyandu Lansia. Jurnal Keperawatan Profesional, 7(2), 85-95.

Arianto, D. N. (2015). Pengaruh komunikasi organisasi dan kompensasi terhadap semangat kerja karyawan. Jurnal Economia, 11(2), 177-185.

Dinas Kabupaten Bantul. (2018). Profil Kesehatan Dinas Kabupaten Bantul Tahun 2018. Yogyakarta: Dinas Kesehatan Kabupaten Bantul.

Dinas Kesehatan Provinsi DIY. (2018). Profil Kesehatan Provinsi DIY. Yogyakarta: Dinas Kesehatan DIY. 
Kementerian Kesehatan RI. (2012). Kurikulum dan Modul Pelatihan Kader Posyandu. Jakarta: Kementerian Kesehatan RI.

Kementerian Kesehatan RI. (2016). Pedoman Umum Program Indonesia Sehat Dengan Pendekatan Keluarga. Jakarta: Kementerian Kesehatan RI.

Kementerian Kesehatan RI. (2018). Profil Kesehatan Indonesia 2017. Jakarta: Kementerian Kesehatan RI.

Marquis, L. B., \& Huston, J. C. (2017). Leadership roles and management functions in nursing (9th ed.). Philadelphia: Lippincott Williams \& Wilkins.

Suprapto, H. A. (2017). Pengaruh komunikasi efektif untuk meningkatkan hasil belajar mahasiswa. Jurnal Ilmiah Kependidikan, XI(1), 13-24.

Wardani, N. I., Martanti, L. E., \& Wahyudi, T. (2019). Pengaruh edukasi dengan media linzi terhadap sikap dan kinerja kader dalam memantau status gizi Balita. Jurnal Kebidanan, 9(1), 24-29.

\section{Copyright and License}

This is an open access article distributed under the terms of the Creative Commons Attribution 4.0 International License, which permits unrestricted use, distribution, and reproduction in any medium, provided the original work is properly cited.

(C) 2020 Ngatoiatu Rohmani, Dewi Utari. 